\title{
Bovine milk production in Campeche: prospects and challenges for rural producers' development
}

\author{
Santillán-Fernández, A. ${ }^{1 *}$; Vargas-Díaz, A.A. ${ }^{1}$; Rosales-Martínez, V. ${ }^{1}$; Fraire-Cordero, S. ${ }^{1}$; \\ Bautista-Ortega, J. ${ }^{2}$; Ireta-Paredes, A.R. ${ }^{3}$; Arroyo-Balán, F.L. ${ }^{4}$ \\ 1 Cátedras CONACyT y Colegio de Postgraduados Campus Campeche, Carretera Federal Haltunchén- \\ Edzna Km. 17.5 Sihochac, Champotón, Campeche, México. \\ 2 Colegio de Postgraduados Campus Campeche, Carretera Federal Haltunchén-Edzna Km. 17.5 Sihochac, \\ Champotón, Campeche, México. \\ 3 Universidad Interserrana del Estado de Puebla Ahuacatlan, Los Llanos km 1, San Andrés Tlayehualancingo, \\ Ahuacatlan, Puebla, México. \\ 4 Cátedras CONACyT y Universidad Autonoma Chapingo, Unidad Regional Universitaria de Zonas Áridas, \\ Carretera Gómez Palacio - Ciudad Juárez Km. 40, Bermejillo, Durango, México. \\ * Correspondence: santillan.alberto@colpos.mx
}

Gitation: Santillán-Fernández, A., Vargas-Díaz, A.A., Rosales-Martínez, V., Fraire-Cordero, S., Bautista-Ortega, J., Ireta-Paredes, A.R., \& Arroyo-Balán, F.L. (2021). Bovine milk production in Campeche: prospects and challenges for rural producers' development. Agro Productividad. https://doi.org/ 10.32854/ agrop.v14i10.1994

Editor in Chief: Dr. Jorge Cadena Iñiguez

Received: April 12, 2021 Accepted: September 14, 2021. Published on-line: November 8, 2021

This work is licensed under a Creative Commons Attribution-NonCommercial 4.0 International license.

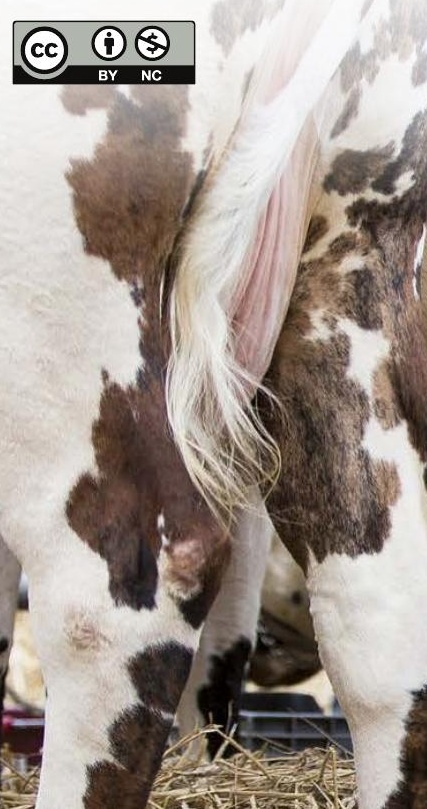

\section{ABSTRACT}

Objective: To characterize at the municipal level the productivity of the bovine-milk sector in the state of Campeche, Mexico; to determine the profitability of the sector and to propose improvement schemes in order to add value to the commercialization of the product.

Design/Methodology/Approach: From the Agricultural and Fisheries Information System, the following variables were obtained: Production (thousands of $\mathrm{L}$ ), Price $\left(\$ \mathrm{~L}^{-1}\right.$ ) and Value of Production (thousands of \$) from 2006 to 2018. Through multivariate statistics and analyses, the profitability of the bovine-milk sector from 2013-2018 compared to 2007-2012 was determined. The analyses were completed by an interview with 12 milk producers who gave added value through the manufacture of cheeses.

Results: A drop in profitability (-8.8\%) was found in the sector from 2013-2018 compared to 2007-2012, despite the increase in production of $6.2 \%$ that did not compensate for the fall in prices $(-14.2 \%)$. The regions with the highest productivity were located from the center to the south of the state: Champotón (24.62\%), Escárcega (17.36\%), and Campeche (16.63\%).

Study Limitations/Implications: Adding value to the milk commodity is a priority need in the short term, to avoid abandoning the activity, which could compromise the economy of rural producers.

Findings/Conclusions: The Mennonite settlements in Campeche have managed to add value to the bovinemilk sector through the manufacture and sale of artisan cheeses. However, the great challenge of the sector is the revaluation of artisan cheeses with market strategies that encourage the consumption of local resources in a context of globalization.

Keywords: Spatial analysis of production, typology of producers, Mennonites, added value. 


\section{INTRODUCTION}

Mexico produces annually around 12 billion liters of milk of bovine origin, and the main producing states are Jalisco (20.27\%), Coahuila (11.27\%) and Durango (10.19\%); Campeche contributes $0.37 \%$ which places it in 23rd place nationally (SIAP, 2018). The production of bovine milk in the state of Campeche is a secondary activity, which complements the dual-purpose livestock farming that predominates in the centersouth of the state (Loera and Banda, 2017). Uzcanga et al. (2015) attributes the low productivity of bovine-milk in the state of Campeche to the deficiencies and in some cases lack of infrastructure, equipment for animal management, and fodder; in addition to insufficient technical assistance and training. Adding to this scenario is the fact that milk is marketed as a commodity product in which quality is not differentiated nor added value provided (Loera and Banda, 2017).

Milk constitutes a basic food basket product in the diet of the Mexican population and is considered key in nutrition for food security (Aguilar, 2015). According to RodríguezGonzález et al. (2015), backyard livestock production in rural communities contributes to food security in developing countries. For their part, Loera and Banda (2017) consider that backyard livestock production should be complemented with marketing schemes that add value to products and improve producers' profitability. In this context, the objective of this study was to characterize the productivity of the bovine-milk sector in the state of Campeche at the municipal level, using multivariate statistics and spatial analysis of production, to determine the profitability of the sector and eventually to propose schemes to improve the commercialization and marketing of the product.

\section{MATERIALS AND METHODS}

\section{Study Area}

This study considered bovine-milk productivity from 2006 to 2018, from the state of Campeche in southeastern Mexico, according to statistics from the Agrifood and Fisheries Information Service (Servicio de Información Agroalimentaria y Pesquera, SIAP, 2018).

\section{Bovine-milk productivity in the state of Campeche}

From SIAP (2018), the following variables were obtained: Production (thousands L), Price $\left(\$ \mathrm{~L}^{-1}\right)$ and Production Value (thousands $\$$ ) at the state level and by municipality, from 2006 to 2018. Temporal regression models were adjusted to determine the evolution in the production and profitability of bovine-milk at the state level (Gujarati, 2007).

\section{Municipal characterization of bovine-milk productivity}

The differences in productivity by municipality from 2006 to 2018 were performed with a Multiple Variance Analysis (MANOVA) and Tukey's means tests with a reliability level of $95 \%$. To determine the regions with the highest bovine-milk productivity in the state of Campeche, annual production by municipality was summed for the period 20062018. The results were grouped into five class intervals: very low, low, medium, high and very high production, and spatially represented with the help of ArcMap 10.3 software (ESRI, 2015). 
In addition, a cluster analysis was used to establish a typology of municipalities; for this purpose, the averages of the variables Production, Price and Production Value were standardized, and with the help of the statistical software R (R-Studio, 2020), the differences between the elements were calculated using the Euclidean distance method and the grouping by Ward's method.

\section{Profitability of bovine-milk productivity at the municipal level}

The profitability of bovine-milk productivity from 2007 to 2018 by municipality was analyzed with the decomposition model of production growth factors proposed by Gómez (1994). The model determines how profitable bovine-milk production is from a base period (2007-2012) with respect to a final period (2013-2018), according to the percentage variations of Production $(\mathrm{L})$ and Price $(\$)$.

\section{Value added to the milk commodity through cheese production}

Through targeted sampling, between January and March 2021, 12 bovine-milk producers were interviewed who have managed to add value to the commodity system by making cheese. The producers were selected based on their availability, leadership and positive references as cheese producers in the state. The 12 producers interviewed were located in the Mennonite farm El Temporal, in the municipality of Hopelchén. The interview was directed at defining the cost-benefit of cheese production and the main points of commercialization.

\section{RESULTS AND DISGUSSION}

\section{Bovine-milk productivity in the state of Campeche}

Bovine milk production in the state of Campeche presented a growing linear trend from 2006 to 2018 (P-Value <0.0001; $\mathrm{R}^{2}=0.9096$ ). According to SIAP (2018), this increase coincides with an increase in the number of animals of $3.5 \%$ per year sustained by Campeche since 1980. However, as shown in Figure 1, the increase in production was accompanied by a fall in prices that impacted the production value. Loera and Banda (2017) found that bovine milk production in Campeche occurs as a secondary activity where meat production is prioritized in the framework of dual-purpose livestock farming; this explains why the activity is maintained even when it seems unprofitable (García et al., 2018).

\section{Municipal characterization of bovine-milk productivity}

The highest indicators of bovine-milk productivity and profitability were obtained in three municipalities, which accounted for $58.61 \%$ of productivity: Champotón (24.62\%), Escárcega (17.36\%), and Campeche (16.63\%) (Table 1). By associating productivity spatially with the hierarchical cluster analysis, two groups were differentiated: the municipalities in one group are similar regarding their productivity, but different from the municipalities in the other group (Pardo and Del Campo, 2007) (Figure 2).

Figure 2 shows that the highest bovine-milk productivity in Campeche was located in the center-south of the state; this is explained by the fact that, historically, livestock 

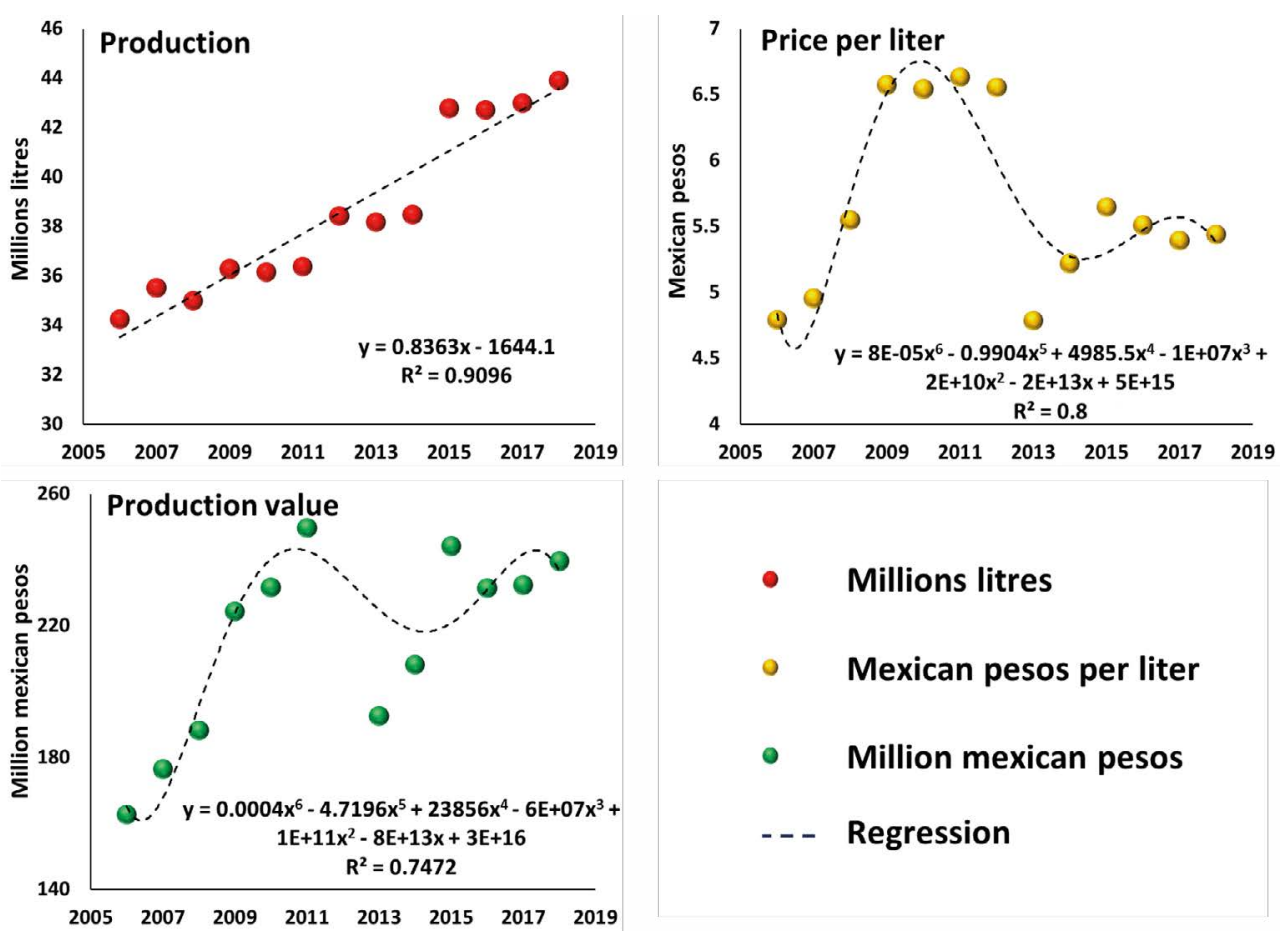

- Millions litres

- Mexican pesos per liter

- Million mexican pesos

- - Regression

Figure 1. Evolution of the production, price, and value of the production of the bovine-milk system in the State of Campeche from 2006 to 2018.

Table 1. Indicators of bovine-milk productivity and profitability from the municipalities in the state of Campeche for the period 2007-2018.

\begin{tabular}{l|c|c|c}
\hline Municipalities & $\begin{array}{c}\text { Production } \\
\text { (Thousands litres) }\end{array}$ & $\begin{array}{c}\text { Price } \\
\text { Mexican pesos } \\
\text { per liter) }\end{array}$ & $\begin{array}{c}\text { Production value } \\
\text { (Thousands mexican } \\
\text { pesos) }\end{array}$ \\
\hline Calakmul & $1399.31 \mathrm{E}$ & $5.22 \mathrm{~A}$ & $7311.74 \mathrm{E}$ \\
\hline Calkiní & $88.45 \mathrm{~F}$ & $5.32 \mathrm{~A}$ & $485.13 \mathrm{E}$ \\
\hline Campeche & $6413.13 \mathrm{~B}$ & $6.13 \mathrm{~A}$ & $38790.79 \mathrm{~B}$ \\
\hline Candelaria & $4950.90 \mathrm{C}$ & $5.87 \mathrm{~A}$ & $29081.74 \mathrm{C}$ \\
\hline Carmen & $4703.61 \mathrm{C}$ & $6.02 \mathrm{~A}$ & $28253.96 \mathrm{CD}$ \\
\hline Champotón & $9492.40 \mathrm{~A}$ & $5.16 \mathrm{~A}$ & $49061.18 \mathrm{~A}$ \\
\hline Escárcega & $6692.69 \mathrm{~B}$ & $5.66 \mathrm{~A}$ & $37899.63 \mathrm{~B}$ \\
\hline Hecelchakán & $686.62 \mathrm{EF}$ & $5.56 \mathrm{~A}$ & $2674.07 \mathrm{E}$ \\
\hline Hopelchén & $446.11 \mathrm{~F}$ & $6.05 \mathrm{~A}$ & $21306.15 \mathrm{D}$ \\
\hline Palizada & $3633.79 \mathrm{D}$ & $5.82 \mathrm{~A}$ & $272.85 \mathrm{E}$ \\
\hline Tenabo & $53.53 \mathrm{~F}$ & $5.10 \mathrm{~A}$ & $\mathrm{E}$ \\
\hline
\end{tabular}

Means followed by the same letter in the column do not differ statistically (Tukey, $\alpha=0.05$ ).

activities have been developed in the south and agricultural activities in the north, with the center being a transition region (Uzcanga et al., 2015). However, according to Loera and Banda (2017) in the south of the state cattle ranching for meat production predominates and in the center-north, dual-purpose cattle production. 


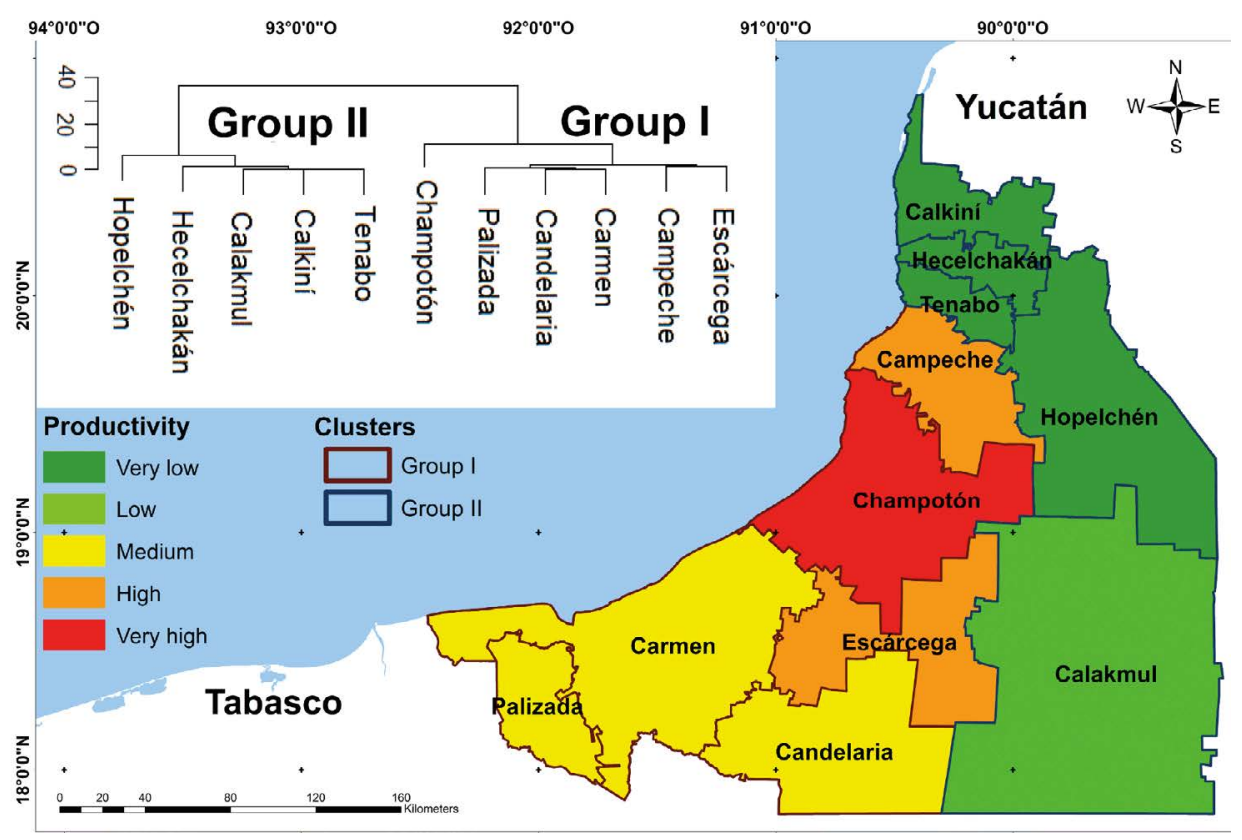

Figure 2. Spatial representation of the typology in bovine-milk productivity at the municipal level in the state of Campeche from 2006 to 2018.

The hierarchical analysis differentiated Champotón as the municipality with the highest productivity in Group I and Hopelchén in Group II. The high productivity of Champotón is explained by the reconversion of agricultural areas to livestock production (SantillánFernández et al., 2020). In the case of Hopelchén, despite not having the same productivity as the central-southern municipalities, it stands out among the municipalities in the north, and this coincides with the settlement of Mennonite groups (Porter-Bolland et al., 2008).

\section{Profitability of bovine-milk productivity at the municipal level}

By the factor decomposition model of production growth (Gómez, 1994), it was found that in 2013-2018 the profitability of producing bovine-milk in the state of Campeche was lower by $-8.8 \%$ compared to the period 2007-2012, despite the fact that there was an increase in production of $6.2 \%$ that failed to cushion the fall in prices $(-14.2 \%)$. According to Loera and Banda (2017) the loss in profitability of the dairy sector can be improved by adding value to the product, and gradually abandoning markets that privilege the purchase and sale of milk as a commodity.

Figure 3 shows that only the municipality of Palizada reduced its production, while the remaining municipalities increased it. However, the fall in prices that the sector has maintained since 2013 (SIAP, 2018) caused only Champotón, Calakmul and Tenabo to have an increase in the profitability of producing bovine-milk; Hopelchén turned out to be the municipality with the lowest profitability. According to Vargas-Godínez and García-Ortega (2018) the low profitability of milk production is a factor that explains cheese production in Mennonite communities of Hopelchén which seek to add value to the bovine-milk product system. 


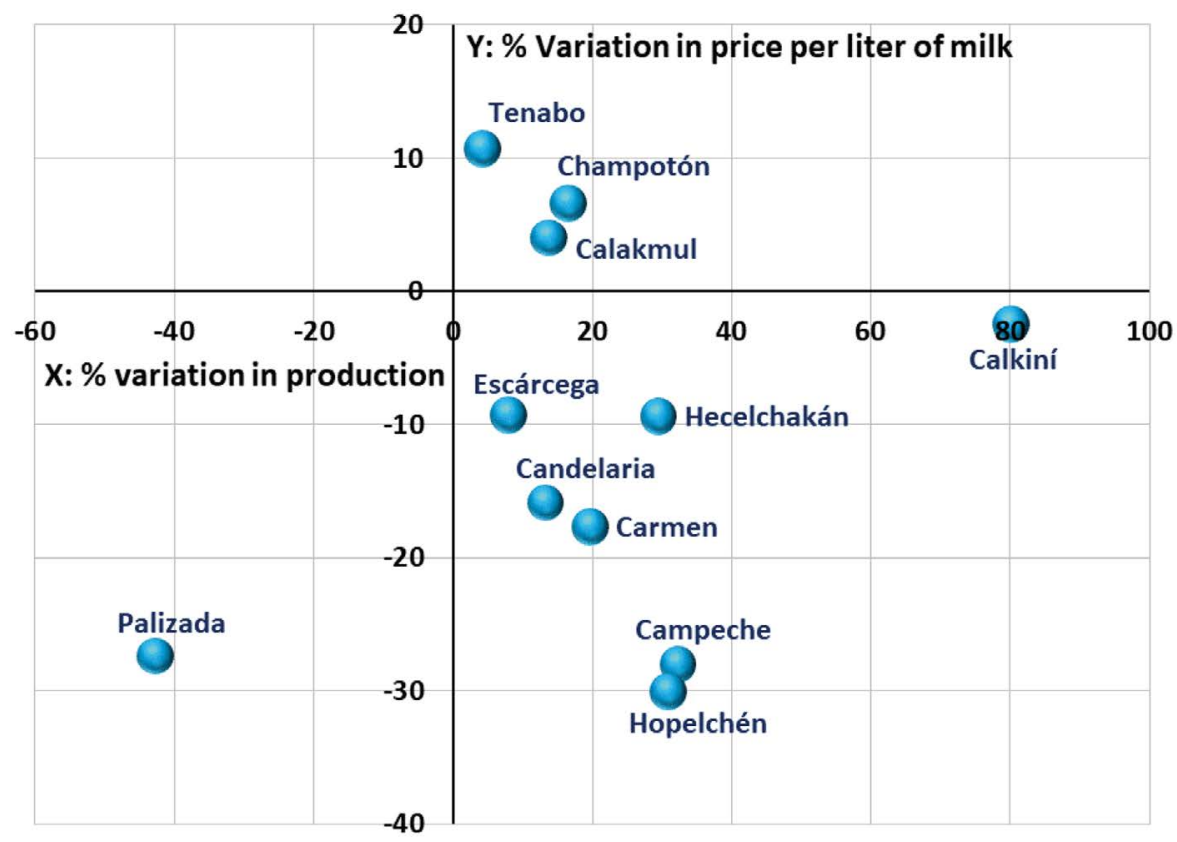

Figure 3. Profitability in bovine-milk production by municipalities in Campeche in 2013-2018 compared to 2007-2012. Municipalities above the x-axis presented an increase in their profitability.

\section{Value added to the milk commodity through cheese production}

The interview with 12 bovine-milk producers in the Mennonite farm El Temporal, in the municipality of Hopelchén, allowed learning that the strategy followed by this community in the face of falling milk prices has been the manufacture of Chihuahuatype cheese or also known as Mennonite cheese. López-Díaz and Martínez-Ruiz (2018) consider that the tradition that Mennonite groups have in the manufacture and marketing of cheese has allowed them to open market niches in southeastern Mexico.

According to the results of the interview, 6 to $8 \mathrm{~L}$ of milk are invested for each $\mathrm{kg}$ of cheese, and a profit/cost of 1.78 is achieved, as a result of a production cost of $\$ 42.00$ and a sales price of $\$ 75.00$. The cheeses are marketed mainly in Mérida, Yucatán (80\%) and the remaining $20 \%$ is distributed in the state of Campeche, with the main destinations being the cities of Campeche, Champotón and Hopelchén. The producers agreed that without cheese elaboration, milk production would be an unsustainable activity for the Mennonite community. Villegas-de Gante and Cervantes-Escoto (2011) consider that southeastern Mexico has great potential for the production of genuine cheeses from cow's milk. Although Campeche has little tradition in cheese making (Agudelo-López, 2015), Grass-Ramírez et al. (2015) found that the transformation of milk into cheese is the easiest way to add value and improve the profitability of rural dairy farmers.

\section{CONGLUSIONS}

The bovine-milk sector in the state of Campeche shows a loss in profitability from 20122018 compared to 2007-2012, as a consequence of a reduction in prices per liter of milk. Given this scenario, adding value to the product seems to be a priority in the short term, 
to avoid the abandonment or reconversion of the activity to other production systems, which could compromise the economy of rural producers in a context of food security. The cheese production and marketing model implemented by the Mennonite community in the north of the state of Campeche can help to improve the profitability of the bovine-milk product system. However, it should be considered that the great challenge for the sector is the revaluation of artisanal cheeses with market strategies that encourage the consumption of local resources in face of a context of globalization.

\section{ACKNOWLEDGMENTS}

This study is part of Project Number 364, "Sustainable productive reconversion for the development of rural producers in Campeche" (Reconversión productive sustentable para el desarrollo de los productores rurales de Campeche), assigned to the first author by the National Council of Science and Technology (CONACyT). We would like to thank the anonymous reviewers of the text for their comments, which helped to enrich the research.

\section{REFERENGES}

Agudelo-López, M. (2015). Atlas de los quesos mexicanos genuinos. Agricultura, sociedad y desarrollo, 12(2), 257 260.

Aguilar, A. (2015). Canasta básica y calidad de la alimentación en México: Felipe Torres, Instituto de Investigaciones Económicas-UNAM, México, 2014. Problemas del desarrollo, 46(182), 191-193. doi. org/10.1016/j.rpd.2015.06.005

ESRI (Environmental Systems Research Institute. ArcGIS Versión 10.3). (2015). Software de procesamiento digital de imágenes satelitales. Redlands, CA, USA. Disponible en http://www.esri.com/software/ arcgis/ arcgis-for-desktop

Santillán-Fernández, A., González-Pérez, G., Bautista-Ortega, J., Huicab-Pech, Z.G., Escobar-Castillo, J., \& Larqué-Saavedra, A. (2020). Brosimum alicastrum Swartz como alternativa para la reconversión productiva de áreas agrosilvopastoriles en Campeche. Revista mexicana de ciencias forestales, 11(61), 51 69. doi.org/10.29298/rmcf.v1 li61.722

García, J.A.E., Izquierdo, A.V., González, S.F.G., Reyes, V.C., Gómez, R.V., \& Maldonado, J.A.R. (2018). Evaluación del impacto en la productividad y rentabilidad de la tecnología transferida al sistema de bovinos de doble propósito del trópico mexicano. Tropical and Subtropical Agroecosystems, 21, 261-272.

Gómez, L. (1994). La política agrícola en el nuevo estilo de desarrollo latinoamericano. Organización de las Naciones Unidas para la Alimentación y la Agricultura. Santiago, Chile. 675 p.

Grass-Ramírez, J.F., Sánchez-Gómez, J., \& Altamirano-Cárdenas, J.R. (2015). Análisis de redes en la producción de tres quesos mexicanos genuinos. Estudios sociales, 23(45), 185-212.

Gujarati, D.N. (2007). Econometría. Cuarta edición. McGrawHill. Pp: 560-571.

Loera, J., \& Banda, J. (2017). Industria lechera en México: parámetros de la producción de leche y abasto del mercado interno. Revista de investigaciones altoandinas, 19(4), 419-426. doi.org/10.18271/ria.2017.317

López-Díaz, J.A., \& Martínez-Ruiz, N.D.R. (2018). Perfil sensorial y fisicoquímico del queso chihuahua considerando las preferencias del consumidor. Agrociencia, 52(3), 361-378.

Pardo, C.E., \& Del Campo, P.C. (2007). Combinación de métodos factoriales y de análisis de conglomerados en R: el paquete FactoClass. Revista colombiana de estadística, 30(2), 231-245.

Porter-Bolland, L., Sánchez-González, M.C., \& Ellis, E.A. (2008). La conformación del paisaje y el aprovechamiento de los recursos naturales por las comunidades mayas de La Montaña, Hopelchén, Campeche. Investigaciones geográficas, (66), 65-80.

Rodríguez-González, S., Schneider, S., \& Coelho-de-Souza, G. (2015). Reconexión producción-consumo: cambio para la seguridad alimentaria y nutricional y el desarrollo rural. Agronomía Mesoamericana, 26(2), 373-385. doi.org/10.15517/am.v26i2.19332

R-Studio (The R Project for Statistical Computing). (2020). Disponible en: https://www.r-project.org/

SIAP (Sistema de Información Agroalimentaria y Pesquera). (2018). Cierre de la producción agrícola. Disponible en https://www.gob.mx/siap/documentos/siacon-ng-161430 Consultado en enero 2021. 
Uzcanga, P.N.G., Cano, G.A.D.J., Medina, M.J., \& Espinoza, A.J.D.J. (2015). Caracterización de los productores de maíz de temporal en el estado de Campeche, México. Revista mexicana de agronegocios, 36(1345-2016-104390), 1295-1305. doi.org/10.22004/ag.econ.200172

Vargas-Godínez, C., \& García-Ortega, M. (2018). Vulnerabilidad y sistemas agrícolas: Una experiencia menonita en el sur de México. Sociedad y ambiente, (16), 137-156.

Villegas-de Gante, A., \& Cervantes-Escoto, F. (2011). La genuinidad y tipicidad en la revalorización de los quesos artesanales mexicanos. Estudios sociales, 19(38), 145-164.

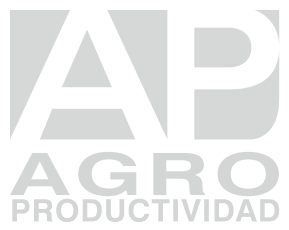

